\title{
Sufism and Pesantren as the Part of Our Islamic and Indonesian Identity
}

\author{
Baedhowi \\ INISNU Temanggung \\ baedhowi@gmail.com
}

\begin{abstract}
Tasawuf or Sufism in pesantren is an important material teaching that Muslims in Indonesia are very familiar. Historically, this social reality is important to understand that the beginning of Islamization here has put forward the nuances of Sufism. Saints and ulama such as Walisongo in Java are teachers of Islamic religion who have a very Sufistic nuance in their teachings. They attach great importance to this esoteric aspect of religion. The characteristic of Sufism that they spread is Ghazalian centric and accommodate social smoothness. In this way, the characteristic of their Sufism can still be integrated with the existing local cultures, so that their wisdom and religiousity can provide peace and enlightenment as well as harmony with the social realities and locality. This article wants to introduce the characteristic of Sufism and role of pesantren as exemplified by the saints (Walis) in Java as an "introductory" paper. This article intends to study the wisdom of the saints (Walis) in Java and the pioneers of the pesantren world in spreading islamicity. They have been chummy to Sufism for the long time in opening wide a model of islamicity and Indonesian identity. In this Context we can understand that Sufism is not only as a complement learning of kalam and fiqh, but also has been the part of religousity in this country for the long time. The smoothness of sufisme is important to transforme a model of Islamicity that is more tolerant, calm, friendly and more Indonesian.
\end{abstract}

Keywords: Pesantren, Sufism, Our Islamicity, Indonesianness

\section{Introduction}

Pondok Pesantren or just call it Pesantren (Dhofir, Zamakhsari, 1979; Berg, 1932 ) is the oldest Islamic educational institution in Indonesia that develope the teachings of Islam of Ahlusunnah wal jama'ah. One of the main materials that is developed in pesantren education, in addition to al-Asy'ari theology, fiqh (Syafi"i in particular) is also Sufism. This Sufiism teaching tradition is actually what has applied in the teaching of Islam in the early time of the entry of Islam. Epistemologically, Sufism or Irfani reasoning (the term Muhammad Abid al-jabiri) is one of the Islamic epistemologies that is built from direct experience (ru'yah mubasyirah, direct experience) and from the normative values of the sacred or holy Texts (the Qur'an and Hadith), and in particular from the empirical social reality of religiosity. Sufism 
is a form of Islamic epistemology which histocally can be said as the earliest form of Islamic epistemology in Indonesia. It is spreaded and came here through the preachers or spreaders of Islam.The most popular saints in Java are Walisongo. These islamic spreaders are traders, wanderers and practitioners of Sufism. They spread Islam to various regions which are then passed on by fiqh and kalam scholars (Nurholis Madjid, 1992).

The application and spreading of Sufism here according to the writer is a genuine islamic Indonesian character. Then in the future it can be used up by the spreaders of islam in building Islamicity and Indonesianness as our identity. In this "introductory" article, the contextualization of Sufism, in addition to being a complement to the learning of kalam and fiqh, it should be developed in shaping the face of Islam which is calmer, friendlier, more tolerant and more Indonesian. This kind of peaceful and friendly Islamic character is actually also a manifestation of "the greatest struggle or jihad" (jihad al-akbar) which is not really the meaning of jihad in the narrow sense as analogous to war, terror and other forms of violence but it is as an attitude and moderation in the reality of pluralism, nationality and its speed global civilization.

Sufism books have been the main material for the long time, especially in salaf (traditional) Pesantren. For example, the books such as Bidayah al-Hidayah, Kifayah al-Atqiya', Minhajul Abidin and his syarah (Mukhamad Dahlan, 1959), al-Hikam, Ikhya' Ulumudddin, Su'ab al-iman, Hidayah al-Azkiyya' ila Tariq Auliya', Risalah alQusyairiyah etc have been known in pesantren. This latter work (Risalah) must not be as popular as the book of al-Ghazali or the work of Ibn Atha'illah (al Hikam) and limited as a collection and reference for kiais in learning Sufism in Pesantren, but at least can provide a systematic description of the stages of level promotion (maqamat) for a salik and God's grace given (hal) to those who are close to Him (Abu Qasim,Qusairy,tth).

From the various books of Sufism that have been known in the pesantren, the writer can assume that the teachings of Sufism that developed in Pesantren in Indonesia can be said to be the image of Ghazalian model. This is caused that almost of all pesantrens in Indonesia, and it's patern are Ahlusunnah, in addition to being in general that al-Ghazali's works have been used as a kind of "mandatory" study in pesantren. 
Al-Ghazali's Sufism chain historically, cannot be separated from the reference sources that used by the spreaders of Islam. They spread Islam to Indonesia, and then were passed on by the ulama and kiai as learning materials in pesantren, such as the Walisongo in Java. Sunan Bonang (1525 AD) for example, is mentioned in the Het Book van Bonang manuscript refers to the book Ikhya 'Ulumuddin by Imam Gazali which was taught by Sah Bari. Therefore, it is not surprising that later alGhazali's work, Ikhya 'Ulumuddin, was used in almost all salafiyah (traditional) pesantren in Java as the main material in the teaching of Sufism. So we can understand that the popularity of Ikhya's book is caused by sufism learnings pesantren and society. It has been also introduced by preachers and propagators of Islam in Java, as can be seen from the reference of Sah Bari, as a teacher of Sunan Bonang. Bari used al-Ghazali's work as a reference material to give advice to students (Drewes, 1969).

The book of al-Ghazali can also be seen from his smaller book, namely Minhajul 'Abidin, that Ikhsan Muhammad Dahlan, from Jampes Kediri gave a syarh with the title Siraj al-Thalibin a la Syarh Minhajul 'Abidin ila Jannah al-Rabbil 'Alamin for the work of al-Ghazali. Althouht this book, is written by a pesantren kiai or Javanese scholar, it also has met a fairly high standard of scholarship. So that according to Gus Dur (Abdurrahman Wachid), the book Siraj al-Thalibin a la Syarh Minhajul becomes mandatory literature for Masters in Sufism studies at al-Azhar University and become a special requirement for students who want to become Kiai candidates in Gambia, Africa.

\section{Learn From the Experiences of the Saints in Java}

Taking religious lessons from the Javanese saints means that we also have to study history reflectively or in the philosophy of history or it is often called reflexive history. That is learning from the past that always be able to take advantage of historical experiences, both in a positive sense to take advantage of it and in a negative sense to avoid bad experiences. Learning history reflectively, especially from the stories of the prophets, apostles and salaf al-shalih normatively and spiritually can also strengthen "faith", reveal the truth and strengthen determination, as mentioned and recommended in the Qur'an, "All which we tell you about some of the stories of the Apostles, may it strengthen your heart in addition to obtaining the truth and teaching and warning for those who believe "(Surah Hud, 
verse 120). Therefore, if Bung Karno once uttered the motto "Jasmerah" (don't forget to history), in this case it means that we must be able to take advantage of historical experiences so that we can take better historical pioneers in the future.

The guardians or saints in Java as pioneers a pesantren learning institution clearly have a very large contribution. It can even be said to be the pioneer of existing pesantren models, although their teaching is still very simple. The efforts of Maulana Malik Ibrahim (d. 1419) in Gresik, East Java, for example, can be said to be an attempt to institutionalize a distinctive and unique educational method at that time which became known as "pesantren". For Ibrahim, who has capital and symbolic capital (Pierre Bourdieau's term) (Bourdieu, 1980), from the results of trade and from the results of social-religious interactions in teaching Islamic values to the community, he then develops it. Then he used the capital and social capital to establish a pesantren. This capital and symbolic capital which was then used by Ibrahim to invite many of his followers and bring the community to his agricultural fields during the day and provide basic teachings, such as the Qur'an and hadith at night. The model of Ibrahim's institution which we can know today as pesantren. Therefore, Malik Ibrahim can also be called the father or teacher of the early pesantren in Java. The pioneering in establishing this kind of pesantren institution which at the same time made Malik Ibrahim also called the spiritual father of Walisongo.

The guardians or saints in Java as scholars, with reference to the Sunnah of the Apostle (Muhammad) want to make it a model for the prophetic mission (qudwah wa uswatun hasanah) in conveying religious discourse and religious attitudes. The burden of carrying out the hadith of the prophet, "al-ulama 'warash al-ambiya' is an obligation and a noble task that is carried out sincerely, selflessly, politely and peacefully, because what they want to inherit are the values of individual and social piety. Therefore, those who glorify the Ulama' are also glorifying Allah and His Messenger, while those who despise the Ulama' are also humiliating God and His Messenger (Hasyim Asy'ari,1990). That religious message is important, especially for the Javanese people who always want a harmonious attitude and idolize figures as the role models. More than that, genially the guardians (walis) can take advantage of the Javanese value system that adheres to the paternalism model with patronclient relationships that have strong roots in society. 
For that reason, the guardians and saints in Java are also very intensely involved physically and mentally in social participation to introduce, explain, and solve community problems and to provide ideal and religious examples in society. This kind of action is actually a perfect disguise of the fact that society needs spiritual leaders who can support, protect, and guide them on the right path. The guardians were then imitated by the next ulama/kiai to become a unifying symbol between local religious leaders and their communities. People can actually accept the leadership of effective and protective guardians, as well as their religious abilities. (Mas'ud, 2004). This historical fact was later confirmed by Mark R. Woodward's study which confirmed the role of Sufis in Indonesia, especially in Java by stating: "The study of Javanese Islam is an attempt to answer M. Hodgson's question about why the success of Islam can be perfect and almost flawless" (Woodward, 1999). Woodward also concludes that "Javanese Islam is not only unique, in that it retains aspects of pre-Islamic culture and religion, but it also related to Sufi concepts of sainthood, the mystical path and human perfection ...traditional Javanese conceptions of social rules, rituals and even aspects of social life such as personality forms... (Woodward, 1999)

From the Sufism learning materials that have been introduced by the saints or Walis in Java (especially Walisongo), These arguments could perhaps explain that historically we can learn that Islam is actually offered by the saints and the pioneers of Pesantren in Java in particular, as a form of Islamic learning is quite mature and can be said to be the "spirit" or "heart" of the Islamic religion (ruh/qalb al-islam) which is more deeply immersed in the inner (esoteric) aspect (Titus, Burhardt, 1969). It is Important to realize that the guardians and saints or the pioneers of the pesantren, usually already understand the exoteric aspects of learning the ilm kalam and fiqh in the sense of sayri'at. These two exoteric and esoteric aspects are often interpreted as the area of shari'ah and nature in Islam. Shari'ah in this case (sufistic glasses) can be interpreted as all God's commands that are carried out as a form of worship or our servitude to Allah.

While the essence of everything (haqiqat) is witnessing all the greatness of God as Rabbul 'alamin. Shari'ah came as a legal burden from God in order to realize our servitude and carry out what He has commanded. While the haqiqat is in order to 
grow evidence of the greatness and majesty of God, and witness what has been confirmed, predestined, what is kept secret and revealed by God (Qusyairi, 1976).

With reference to al-Ghazali's book above the saints and pesantren pioneers, at least empathically and epistemologically also follow and practice the ideas that has been developed by al-Ghazali's thought. It should also be noted that the phenomenal contribution of Al-Ghazali's thought in the field of Islamic education was his attempt to compromise esotericism and exotericism, which at that time had intense polemics. From the focus on al-Ghazali's thoughts, according to the writer, what is no less important in observing a product of thought is that although al-Ghazali's thinking remains a reference in pesantren, al-Ghazali's Sufism should be read critically as a thought that is not empty of historical space and nuances of ideological defense (Sunni) (Baedhowi, 2004).

The flow of al-Ghazali's Sufism and thought in the pesantren world can be seen from the work of al-Ikhya 'Ulumuddin, which is half (Juz I, II) focused on the study of shari'ah in a limited sense (fiqh) and its inner secrets. While on the juz III and chapter IV are descriptions of rubu'ul al-muhlikat, namely (a quarter) of various destructive morals, such as arrogance, greed, showing off (riya'), ujub, overambitious to rise in rank and wealth (hub al-jah/riyasah, wa al-mal), and so on. While on the last part is rubu'ul al-munjiyat, namely (a quarter) of various morals that will save from the joints of life in the world to the hereafter, such as sincerity, taubah, wara', zuhud, qana'ah and so on (al-Ghazali, 1971).

From this kind of al-Ghazali thoughts, he wants his readers to be able to practice religion (Islam) intensely and correctly both theologically and shari'a accompanied by a deep belief in the inner values (sufism) of this practice. In other words, al-Ghazali wants to combine and harmonize the exoteric (shari'ah) and esoteric (sufism) aspects of Islam. Harmonization of aspects of Shari'ah and Sufism with slightly different terms-according to the writer, it is also the efforts of subsequent scholars, such as Ibn Khaldun, Ibn Taimiyah, Fazlur Rahman, Hamka, Mohammed Arkoun and others (Khaldun, 2004; Rahman, 1998; Siradj, 2006; Baedhowi, 2013).

With the harmonization of the two aspects of Shari'ah and Sufism, it is hoped that it will become a balanced character (tawazun), moderate (tawasuth), and tolerant (tasamuh) between outward and inner aspects so that the implications will 
be seen in good behavior and morality. Therefore, from a historical point of view, the journey of teaching Sufism is not only obvious in pesantren, it is also well established, especially in older pesantren. Even the characteristic or dominance of Sufism according to Azumardi Azra has been increasingly established since the 18th century in pesantren and the like, such as meunasah or dayah in Aceh, surau in Minangkabau, and the Malay Peninsula. Therefore, it can be said that Sufism has been the basic character of life in pesantren (Azra, 1998).

By studying the history of Sufism in the pesantren, we hope that we can pick the pattern of Islam that should be preserved and can be developed in religious life in our country (Qomar, 2001). The learning of Sufism that wants to be developed from the past experiences is none other than a comprehensive Islamic, both aspects of kalam or theology, aspects of shari'ah or fiqh in a narrow sense, both of which reflect Islamic exotericism and Sufism as the spirit and "heart" of Islam and religion. , (le Couer de l'islam), -borrowing the term Khaled Bentounes- (Bentounes, 2004). So theese aspects of Islamic esotericism are essensials as well as a form of Islamic epistemology and the perfection of learning akhlaqul karimah and always able to make peace with the locality and existing cultures. Even so, Bentounes also realized and saw the shift in sufism terms and Sufism practices from the time of the Prophet and the Companions which were never explicitly mentioned but practically could be felt. In contrast to today, the terms and words of Sufism are everywhere but practically cannot be felt and are rarely practiced.

\section{Results and Discussion}

\section{Sufism Epistemology}

Epistemologically, the Sufism in the concept of Muhammad Abid al-Jabiri can be included in Irfani's epistemology (Jabiri, 1990). The existence of the Irfani tradition historically found its form as it is today, it can be traced from the Hellenistic period ((late IV century BC) and the end of the Greek heyday period (mid VII century AD). This term is then specifically better known in Islamic mystical terminology with the meaning ma'rifah in the sense of knowledge of God. In philosophical discourse (Islam), irfan can be associated with the philosophical school of gnosticism, this knowledge is called gnosis, namely knowledge that is obtained by people not through the mediation of reason or the senses but through mystical awareness which is achieved directly through inspiration from God or 
through certain ascetic practices (riyadhah, mujahadah, ru'yah mubashshirah and the like).

Seeing the origin of irfani sources that are not from the sacred text, and all the Abrahamic religions before the arrival of God's revelations and messengers (qablal bi'sah) adopting Greek thought, then irfani or gnosticism can be found in all heavenly or Abrahamic religions (Judaism, Christianity and Islam) with the incarnation and different forms and characteristics according to their respective traditions and teachings. The history and roots of Sufism in Islam to become irfan can be found in the Shi'a tradition of thought, especially in Persia as a combination of philosophy and Sufism. They even changed the name of Sufism to Irfan (gnosis). According to them, philosophy is not only a rationalistic paripatetic heritage, but also includes discursive philosophy (bahsi) and intuitive philosophy (dzauqi) and is even synonymous with theosophy (hikmah). Therefore, Sufism should not only be understood as practical Sufism, but also beyond being irfan or commonly called philosophical Sufism. In this view, Sufism then becomes a world view or school of thought.

The significant note that we need to pay attention to is the change of Sufism into irfan and the differences in the context of Shi'i and Sunni. In the Sunni Sufism tradition, the concept of ma'rifah or irafani is one of the highest attainment models to reach Allah so that in the Sunni context it is used as an attitude as well as a goal (ghayah/goal). While irfan in the Persian (Shi'i) tradition, which is compatible with ma'rifah, Sufism is the main principle in all achievements of the mystical path that combines all theosophical ascents, Sufism also take its roots from the philosophical tradition. While irfani as a vehicle for the Sufis, the community of batini and masyriqiyyin are called al-Jabiri with ashab al-ma'rifah.

Under the influence of ashab al-ma'riah, the concept of irfani was later developed as mauqif, a condition in which a person through an understanding of himself finds his true nature or identity, so that he is able to "escape" or be free from the grip of nature and material reality so that it "unites" with God. Because God is alhaqiqah al-ulya, then when he meets God all other essences are embedded in his heart. The heart here does not mean the physical heart or the physical part of the body that is on the left side of humans, but it'means as the spiritual soul. 
This heart (qalb) is utilized as a means of belief in and conquering lust and great struggle, as constant reference to God, and shame in actions and concepts, submission and elimination of desires that are placed on a Justice that cannot be denied (Arkoun, 1984). The view of the mystical world above describes a way to enter the spiritual world that can be practiced by everyone who believes in it with perception and through the totality of direct union with God (Arkoun, 1984).

The essence of Sufism according to Mohammed Arkoun refer to an involutive psychology (tadmin: introspection/step inward). To enter this world, there are three levels that must be explored in human nature (nasutiyya): First and most outwardly is understanding the intricacies of the soul or lust (nafs) as a means of the greatest struggle (jihad al-akbar) to transcend the various stages (maqamat)/stations), namely: 1. tawbah, 2. wara' 3. zuhd, 4. faqr, 5. sabr, 6. tawakal and 7. ridla, until reaching the second level, the esensial heart. The heart is the most appropriate and effective place for comparison (muqabala), various interrelated resistances, such as raja' - khawf, bast - qabd, uns - hayba and so on. A man or salik who practices the maqamat can know that al-ahwal is as a gift given by God because of the purity of his heart or his soul and mental readiness (especially with the preparation and practice of mujahadah in maqamat), so he gets a pleasure or the peak of his experiences (extace). Then he feels the point of experiencing encounter with God (ittisal) and union with Him (ittihad) (Qusairi, 1976; Arkoun, 1984; Baedhowi, 2013).

\section{Sufism and Our Identity: The More Islam the More Indonesia}

By looking at past experiences and the changes that are happening in our country in particular and in various parts of the world in general, Sufism education has a very significant role. Especially with the radical changes in various sectors of life and the crises that hit this nation, the Arab nations etc. Such changes are clearly not only directed and are purely economic and political in nature, but have entered a very basic and fundamental area, namely issues of spirituality, moral crisis, and the problems of identity so that we almost lose hope. The hope to be able to get out of the atmosphere of "social pathology" and complete moral decadence like that, is actually believed to be solved by learning Sufism and will emerge from the world of Pesantren or spring up the figures from pesantren. In the Indonesian context, the pesantren world will at least be a very promising hope in the example of morality 
and spirituality in order to get out from the nation's multidimensional crisis.( Abd Munir Mulkhan, 2003)

Moreover, when many groups of this nation, torn apart by sectarianism, prioritize their own personal and group interests. The people from pesantren who have well-established Islamic knowledge and are consistent in their work will realize that they must also be part of the plural, multi-religious, ethnic, and cultural problem of Indonesia. The Islamic model in the Indonesian context is at the same time a differentiator from the Islamic model that developed in various Arab or nonArab countries which was spreaded through military expansion and is more political in nature. Islamic character in this way seems to be more formal, full of compulsion and more touching on the exoteric (outward) aspects of religion. It is important to emphasize this historical experience because Islam that came to the homeland was indeed a Sufi character. Moreover, the phenomenon and image of Islam in Indonesia lately is also often associated with a number of violence, terrorism, intimidation and coercion that carry the label of Islam.

Therefore, Pesantren with the teachings of Sufism is a forum for the Islamic education system which historically has no small and doubtful contribution in empowering human resources towards humans or a civilized Indonesian nation. What we hope for from the pesantren - by borrowing a classical Arabic dictum- is alMukahafadzah 'ala al-Qodimi al-sholih wa al-akhdzu bi al-jadid al-aslah (maintaining the legacy of good and old traditions and adopting new,or better traditions). )-, Therefore we can continue to fight for the education that has been pioneered by the pesantren kiais, sufisme scholars and the salaf al-shalihin while continuing to innovate for a better future. (Mas'ud et al., 2006).

Such an Islamic character, islamic learning should not only study Islamic discourse in pieces and partially so that in its application shows rigid characters, but it is also able in line with the social reality and our pluralistic society. Partial and incomplete of Islamic learning will also lead to disharmony both against fellow Muslims and religious communities. That such religious praxis is easy to blame others and only rely on truth claims and one's own beliefs. For example, we can see this kind of worry and concern from the section on the "suluk" that is noted as singiran of Gus Dur (Abdurrahman Wachid), which writer translates freely: 
Duh poro konco, priyo wanito

Ojo mung ngaji syari'at beloko

Gur pinter dongeng, nulis lan moco

Tembe burine bakal sengsoro

((Hi friends, ladies and gentlemen; Don't study only the Shari'ah; Those who are only good at telling stories and reading; But in the end he will be miserable)

\section{Akeh kang apal Quran hadiste}

Seneng ngafirke marang liyane

Kafire déwe gak digatekke

Yen isih kotor ati akale

(Many people memorized the Qur'an and the Hadith of the Prophet, who liked to disbelieve in others, while the unbelievers themselves were never noticed, As a sign, their hearts and minds were still dirty)

Kang aran sholih, bagus atine

Kerono mapan sari ngilmune

Laku thoriqot lan ma'rifate

Ugo haqiqot manjing rasane

(The so-called pious (people) are good-natured; Because they have solid knowledge, their thoriqot and ma'rifat behavior; Also the truth seems to have disturbed him)

From the lyrics of the song (singiran) above, at least we can see various religious and Indonesian phenomena holistically, both aspects of shari'a or tariqat and ma'rifat, all of which should be able to seep into the essence of Islamic values and sincerity as has been exemplified by the guardians in Java. By perceiving sufisme as Islamic teachings holistically, it is hoped that it will certainly form pious individuals, both rituallly-individually pious and socially pious. In that way, it is necessary for us to cultivate Islam and Indonesianness that is friendly, polite, calm and peaceful. Instead of showing a Muslim face that is angry, sangar (fierce), and full of terror, that makes our milieu uncomfortable and makes many people nervous. The face of Islam like this is clearly not the face of Islam which is "rahmatan lil 'alamin" but rather the face of Islam which is "la'natan lil 'alamin".

From the phenomenon above. friendly and polite attitude and behavior in the application of Islamic values in the current context, would be a necessity and " The Greatest Jihad" in building the nation's character through the wealth of Islamic and Indonesian values that have been passed down to us. This kind of jihad, must be interpreted broadly in various sectors of life, in accordance with the our professions as offered by researcher Lukens Bull. That way can be done through education 
development and character building, in the sense of educating the nation, through poverty alleviation, through cultural and social activity and so on (Alan Lukens-Bull, 2004).

The Greatest Jihad (Jihad al-akbar) that offered by the pesantren world and pesantren kiais also will be refute Samuel Huntington's thesis which predicts a clash of civilizations between Islam and the West and assumes that Islam and modernism cannot be combined and harmonized (Huntington,1993). Bull's research actually proves that through his various efforts, the pesantren world has broken Huntington's thesis. Pesantren kiais and spreaders of sufism are sociables, They have tried to form a new identity that can selectively borrow from the West without being exposed to the bad side effects of modernism, such as materialism, egoism, free sex, and avoiding religious fundamentalism. Thus, the pesantren community has carried out changes in society and the better character identity through education, good example, and da'wah, than through violent conflict. In Bull's terms, the efforts of pesantren can be called as "a peaceful jihad". This Greatest Jihad that must be defined and interpreted as a peaceful struggle to achieve individual and collective moral fulfillment.

\section{Conclusion}

The saints or spreaders of Islam, like Walisongo in Java are Sufi figures who in addition to teaching exoteric aspects of Islam, such as kalam and fiqh, they are also very concerned for teaching and learning the esoteric aspects of islam, such as Sufism. The spreaders of islam and saints have tauch the Islamic material with the Sufistic pattern. That is the way that causes their approach to preaching Islam always adapt to the richness of local cultures and wisdom in a tolerant and peaceful manner perfectly so their teaching can be accepted by the society- to borrow the statement of Hudgson. This method is actually a mission of $d a^{\prime}$ wah and humanity of the spreaders of Islam in spreading and perfecting the mission of Islam holistically (kaffah). With this model of Islamic learning and the sufistic wisdom of the spreaders of Islam, especially with the examples of pesantren kiais can be hoped and expected to be the basis for our religiousity and muslims identity without having to throw away our Islamic characteristic, national identity and Indonesianness. 


\section{Bibliography}

Al-Jabiri, M. A. (1990). Bunyah al-Aql al-Arabiy Dirasah al-Tahliliyah li Nuzum alMa'rifah fi al-Thaqafah al-Arabiyah. Beirut: Markaz Dirasah al-Wihdah

Al-Jampisi, I. M. D. (1954). Syiraj al-Thalibin, Syarh 'ala Mihajul 'Abidin ila Jannah Rabb al-'Alamin. Surabaya: Sirkah Muhamad Sulaiman Sa'id

Arkoun, M. (1984). Essais sur la pensee Islamique. Paris: Maisonneuve et Larose

Arkoun, M. (1984). L'Humanisme arabe au IVe/Xe siècle. Paris: Vrin.

Arkoun, M. (1995). "Clearing up the Past to Preparate the Future". Article in ICCT, Yogyakarta

Azra, A. (1989). Prespektif Islam di Asia Tenggara. Jakarta: Yayasan Obor Indonesia

Baedhowi. (2003). Tasawuf Sebagai Jalan Akhir Menuju Kebenaran: Kajian atas Pemikiran al-Ghazali. Millah. Vol. II, No. 2

Baedhowi. (2007). Humanisme Islam. Yogyakarta: Pustaka Pelajar

Baedhowi. (2013). Disertation. UIN Sunan Kalijaga Yogyakarta

Bentounes, K. (2004). Le Couer de l'Islam. Paris: Poche

Berg, C.C. (1932). "Indonesia" dalam HAR Gibb (ed.) Whiter islam ? A Survey of modern Movement in the Moslem World, London,

Bourdeau, P. (1990). Le Sens pratique. Paris: Minuit

Burckhadt, T. (1969). Introduction aux doctrine esoteriques de l'Islam. Paris: DervyLivres

Dhofir, Z. (1979). Tradisi Pesantren. Jakata: LP2ES

Douglas, W. A. (1972). "Epistemology" in William Denton, Encuclopedia of Britanica. Chicago: Encyclopedy of Britanica

Ghazali, A. H. (1346 H). Ihya' Ulumuddin. Kairo: Mustafa Bab al-halbi

Ghazali, A. H. (n.d), Minhajul Abidin, Surabaya: Syirkah Maktabah Salim Said.

Gilles, Q. (1987). “Gnosisme” in Merea Eliade, (ed.). The encyclopedia of Religion, Vol, 5, New York: Mac Millan Publishing \& Co

Huntington, S. (1993). “Clash of Civilization” in Foreign Afairs, Vol 72, 3

Khaldun, I. (2004). Muqaddimah. Kairo: Dar al-Fajr li al-Turats

Kuntowijoyo. (1991). Paradigma Islam Interpretasi untuk Aksi. Bandung: Mizan

Lukens-Bull, R. A. (2004). A Peaceful Jihad: Javanese Islamic Education and Religious Identity Construction. (Abdurrahman Mas'ud, et al. Trans.), Jihad ala Pesantren di Mata Antropolog Amerika. Jakarta: Gama Media

Madjid, N. (1992). Bilik-Bilik Pesantren, Sebuah Potret Perjalanan. Jakata: Paramadina

Mas'ud, A. (2004). Intelektual Pesantren Perhelatan Agama dan Tradisi. Yogyakarta: LKiS 
Mas'ud, A. et al. (2008). Dinamika Pesantren dan Madrasah. Yogyakarta: Pustaka Pelajar dengan Fak Tarbiyah IAIN Walisongo

Mulkhan, A. M. (2003). Menggagas Pesantren Masa Depan. Yogyakarta: Qirtas

Mustofa, S., et al. (n.d). Administrasi Pesantren. Jakarta: PT Prayu barkah

Qomar, M. (n.d). Pesantren dari Transformasi Metodologi Menuju Demokratisasi Institusi. Jakarta: Penerbit Erlangga

Qusyairi, A. K. (n.d). Risalah al-Qusyairiyyah fi 'Ilm al-Tashawuf. Mekkah: Haramain

Rahman, F. (1982). Islam and Modernity. Tranformation of an intelectual Tradition. Chicago \& London: The University of Chicago Press

Siroj, S. A. (2006). Tasawuf Sebagai Kritik Sosial. Bandung: Mizan

Woodward, M. R. (1999). Islam Jawa; Kesalehan Normatif Versus Kebatinan. (Hairus Salim, Trans.). Yogyakarta: LKiS 